\title{
STUDIES ON INTRAVASCULAR HEMOLYSIS IN MAN. THE PATHOGENESIS OF THE INITIAL STAGES OF ACUTE RENAL FAILURE
}

\author{
By C. R. B. BLACKBURN, W. J. HENSLEY, D. KERR GRANT,1 AND F. B. WRIGHT \\ WITH THE TECHNICAL ASSISTANCE OF B. SLARKE
}

(From the Clinical Research Unit,2 Royal Prince Alfred Hospital, Sydney, Australia)

(Submitted for publication May 11, 1953; accepted February 10, 1954)

Intravascular hemolysis of moderate or severe degree in man is often followed by acute renal failure. Most studies of renal function have been carried out on patients during or after the oliguric or anuric phase and have, therefore, shed little information on pathogenesis of the renal failure.

The present studies were undertaken to clarify the changes in renal function which precede anuria resulting from intravascular hemolysis. It was hoped that the onset of acute renal failure might be prevented if the means of reversing the early changes could be found.

The changes in renal function in 10 patients during intravascular hemolysis induced by the intravenous infusion of distilled water are described in this report. The infusions were given slowly, carefully controlled, and often continued for many hours. The resulting alterations in renal function rapidly returned toward normal after the infusion of water was discontinued or after the intravenous injection of Parathormone.

The initial justification for this study rested on observations of the changes in renal function in a patient during and after the accidental intravenous infusion of distilled water. She developed anuria but urine flow was reestablished and her inulin clearance returned to normal 30 minutes after the intravenous injection of Parathormone. Twelve weeks later her inulin clearance was $140 \mathrm{ml}$. per min. per $1.73 \mathrm{~m}^{2}$, Diodrast clearance $420 \mathrm{ml}$. per min. per $1.73 \mathrm{~m}^{2}$, but $\mathrm{Tm}$ Diodrast was only $11 \mathrm{mg}$. per min. per $1.73 \mathrm{~m}^{2}$. Clinical assessment of her renal function, including urine concentration tests, during the next three years has revealed no abnormality.

Patients with impaired renal function, as shown by a urine concentration test and routine clinical

\footnotetext{
1 Medical Board Fellow in Medicine, 1951.

2 Supported in part by a Grant from the National Health and Medical Research Council.
}

tests, were excluded from the present study. A urine specimen of specific gravity of at least 1020 was required before subjects were accepted for study.

At first the only patients studied were those with Hodgkin's disease, lymphosarcoma, or leukemia who were receiving X-ray treatment. Some patients without malignant disease were studied after the experimental procedures proved safe. Two of our experimental patients died some months after the studies were completed, of lymphatic leukemia and lymphosarcoma, respectively, and autopsy examinations revealed no renal abnormality which could be attributed to intravascular hemolysis.

Many investigators have failed to demonstrate renal failure during or after the infusion of hemoglobin solutions in man and experimental animals unless other abnormalities were present, for example hypotension (Rosoff and Walter [1]) or anaphylaxis (Mason and Mueller [2]). Landsteiner and Finch (3) and Voris (4) gave massive intravenous infusions of distilled water but described no instance of renal failure though detailed studies of renal function were not reported. Amberson, Jennings, and Rhode (5) reported oliguric reactions twice in a series of 77 infusions of hemoglobin solutions. On the other hand, Miller and McDonald (6) regularly demonstrated changes in renal and cardiovascular function in 26 normal subjects following the infusion of pure hemoglobin solutions and of freshly lysed red blood cells. The latter authors did not report any severe or permanent renal damage following their experimental procedures.

\section{METHODS}

Subjects: Nine of the 10 experiments were carried out on patients receiving X-ray therapy for leukemia, lymphosarcoma, or Hodgkin's disease. Some data regarding these subjects are set out in Table I. 
Design of experiments: Inulin and Diodrast clearances were measured by the standard techniques of Goldring and Chasis (7) in the fasted but continuously hydrated patient. The inulin and Diodrast infusion, made up in 4 per cent glucose-water, entered a vein in one leg and an infusion of 4 per cent glucose-water was run into a small vein of the opposite ankle or foot. Both these infusions were given at a rate of $4 \mathrm{ml}$. per minute, a total of $8 \mathrm{ml}$. per minute. Venous blood specimens were collected from one arm and measurements of blood pressure were made by sphygmomanometry on the other arm. Catheterization of the bladder, starting the infusions and general setting-up for the experiments usually took place 1 to 2 hours before the control observations were made. After two to five control periods distilled water was substituted for the 4 per cent glucose-water infusion and was usually given at the same rate of $4 \mathrm{ml}$. per minute. After discontinuing the distilled water infusion glucose-water was again given to maintain a constant intravenous infusion rate. Clearance periods were usually 15 to 40 minutes but were prolonged when oliguria was pronounced. Blood pressures, pulse rates, and oral temperatures were usually recorded each 20 to 30 minutes. No significant changes were observed in venous pressures which were recorded in antecubital veins with a saline manometer.

Chemical methods: Inulin was determined by Little's (8) method, Diodrast by Alpert's (9) method, and urine hemochromogen concentration by Bing and Baker's (10) method. Plasma hemochromogen concentrations were estimated by the method of Hunter, Grove-Rasmussen, and Soutter (11) so that determinations could be made each few minutes during the experiments. All clearances have been corrected to a standard surface area of 1.73 square meters.

Renal vascular resistances: Resistances were calculated from the equation $R=\frac{P m \times 1328}{R B F}$ where $R=$ renal vascular resistance, $\mathrm{Pm}=$ half the sum of the values for the systolic and diastolic arterial blood pressures and RBF = the renal blood flow in $\mathrm{ml}$. per second calculated from the Diodrast clearance and the hematocrit value.

Hemoglobin solutions were prepared from an appropriate volume of the patient's own blood, say $300 \mathrm{ml}$., collected 24 to 30 hours prior to the experiment. Prepa- ration of the cell and stroma free solution was by standard methods involving red cell washing, freezing and thawing, centrifuging and Seitz filtering. All operations were carried out at $4^{\circ} \mathrm{C}$. Concentrations were adjusted in the final saline-hemoglobin solution so that a rate of infusion of $4 \mathrm{ml}$. per minute could be continued without lowering the plasma hemochromogen concentration.

Parathormone (Eli Lilly \& Co.) for intravenous injection was either the freshly delivered solution, or solutions which were relatively inactive as the result of autoclaving or of being stored for many months beyond the maker's date of expiration. On two occasions an infusion of Parathormone in 4 per cent glucose-water was used instead of a single intravenous injection. The type of Parathormone preparation injected made no significant difference to the patient's response with regard to the renal functions considered in this paper (12).

\section{RESULTS}

The detailed results of the studies on 10 patients are set out in Table II. Seven developed significant oliguria during the water infusion. The infusions were continued for many hours and were usually stopped when the patients began to show evidence of adverse psychological reaction such as restlessness and distress from hunger, fatigue, and stiffness in immobilized limbs. Sedation with barbiturates was always minimal.

In these 10 patients, age, sex, the nature of the disease process and the previous experience of blood transfusion appeared to have no influence on the occurrence of an oliguric reaction.

Systemic effects were minimal. The arterial pressure rose slightly in two patients one of whom was hypertensive before the experimental study. Transient, variable and minor changes in blood pressure were attributed to inadequacies of standard sphygmomanometry and to psychological reactions rather than to intravascular hemolysis. Five of the patients had febrile reactions during

TABLE I

Clinical data on 10 patients who received intravenous infusions of distilled water

\begin{tabular}{|c|c|c|c|c|c|}
\hline Subject & Sex & Age & Diagnosis & Hematocrit & $\begin{array}{l}\text { Oliguric } \\
\text { reaction }\end{array}$ \\
\hline $\begin{array}{l}\text { 1. PAY } \\
\text { 2. PAT } \\
\text { 3. ELL } \\
\text { 4. FER } \\
\text { 5. SMI } \\
\text { 6. NEE } \\
\text { 7. FLO } \\
\text { 8. QUE } \\
\text { 9. HUG } \\
\text { 10. SOF }\end{array}$ & $\begin{array}{l}\mathrm{M} \\
\mathbf{M} \\
\mathrm{M} \\
\mathrm{M} \\
\mathrm{M} \\
\mathrm{M} \\
\mathrm{M} \\
\mathrm{M} \\
\mathrm{M}\end{array}$ & $\begin{array}{l}36 \\
35 \\
43 \\
52 \\
31 \\
43 \\
32 \\
41 \\
55 \\
26\end{array}$ & $\begin{array}{l}\text { Chronic myeloid leukemia } \\
\text { Acute myeloid leukemia } \\
\text { Lymphosarcoma, Hypertension } \\
\text { Lymphosarcoma } \\
\text { Hodgkin's disease } \\
\text { Chronic myeloid leukemia } \\
\text { Hodgkin's disease } \\
\text { Lymphosarcoma } \\
\text { Chronic lymphatic leukemia } \\
\text { "Neurasthenia" }\end{array}$ & $\begin{array}{l}0.43 \\
0.40 \\
0.48 \\
0.50 \\
0.44 \\
0.37 \\
0.47 \\
0.37 \\
0.38 \\
0.46\end{array}$ & $\begin{array}{l}+ \\
+ \\
+ \\
+ \\
+ \\
+ \\
+ \\
-\end{array}$ \\
\hline
\end{tabular}


or after the experiments ended and the following elevated oral temperatures were recorded : $38.4^{\circ} \mathrm{C}$ in PAT 20 minutes after the study ended and persisting for 6 hours; $38.6^{\circ} \mathrm{C}$ in SOF 30 minutes after the study ended and persisting for 2 hours; $38^{\circ} \mathrm{C}$ in PAY 1 hour before the study ended and persisting for 1.5 hours; $38.2^{\circ} \mathrm{C}$ in QUE in the last period, reaching $39.2^{\circ} \mathrm{C} 1$ hour later but falling in the next 2 hours; $38^{\circ} \mathrm{C}$ in SMI at the end of the study, $39.6^{\circ} \mathrm{C} 1$ hour later and falling to less than $38^{\circ} \mathrm{C} 3 \frac{1}{2}$ hours after the study ended. These reactions were attributed to the manipulations of the experiments and to the presence of traces of pyrogens in the infusions which had been given for many hours.

The manifestations of "transfusion reaction" were completely absent. Backache was never more than mild and, presenting with a slow onset after some hours of flat recumbency, was not unexpected.

Oliguria developed in the same manner in all of the seven patients who showed it. Urine flow started to diminish shortly after the infusion of water was begun and continued to decrease until steps were taken to increase it. In four patients, at the depth of oliguria, the urine volume was virtually zero during 20 to 30 minute periods. Progressive oliguria was always associated with progressive decrease in Diodrast clearance, with a fall in inulin clearance in six patients, and a rise in filtration fraction in four patients. Hemoglobinuria usually accompanied or immediately followed significant oliguria.

Validity of renal clearances: Inulin and Diodrast clearances were considered to indicate glomerular filtration rate and renal plasma flow, respectively. Extraction ratios were not performed but normal ratios were assumed since Miller and McDonald (6) found normal ratios in similar experiments. Other investigators (13) clearly demonstrated that inulin and $\mathrm{PAH}$ clearances were valid in the dog until the renal blood flow fell to about 3 per cent of normal, a decline far greater than we ever observed. Finally the changes in renal function in our patients were rapidly reversible and $U / P$ ratios for inulin always rose as urine volume decreased.

Collection periods of 20 to 40 minutes are too short for the accurate measurement of urine flows of $0.5 \mathrm{ml}$. per minute and less and the uretero- pelvic dead space is large in comparison with the collected urine volume. Clearances calculated for the periods of minimum urine flow will be too low whilst those for the periods immediately following will be too high. Renal storage and release of Diodrast may exaggerate the errors in the calculation of some clearances. In spite of these errors the continuous series of clearances are taken to indicate the magnitude and direction of the changes in filtration rate and renal plasma flow in each patient.

Diodrast clearances: A highly significant direct correlation developed between the rate of urine flow and Diodrast clearance during the infusion of distilled water. Prior to the infusion of distilled water the coefficient of correlation was low and not significant $(r=0.08, n=30$ and $\mathrm{P}=>0.1$ ) but during the infusion of distilled water the correlation coefficient was higher and highly significant $(r=0.54, n=41$ and $P<$ 0.001 ). Correlation coefficients were derived from the logarithms of the data obtained from all 10 patients during the control period and during the infusion of distilled water but the data obtained during or after the infusion of Parathormone were excluded.

Renal plasma flow was reduced in the seven patients who developed oliguria during the in-

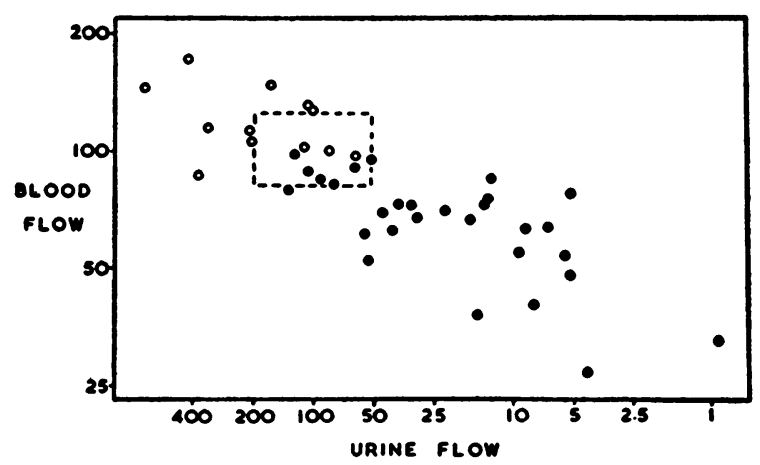

Fig. 1. Relationship between the Change in Renal Plasma Flow $\left(C_{D}\right)$ and the Change in Urine Flow in 10 Patients during the Intravenous InfuSion of Distilled Water

$C_{D}$ and UV are both plotted as percentages of the mean control values ( 100 per cent) for each patient. The area included by the dotted lines represents the mean $\pm 2 \sigma$ of all the control $C_{D}$ and UV values. Solid circles represent the data from the seven oliguric patients, the closed circles the data from the three patients without oliguria. 
TABLE II

The effects of intravenous infusions of distilled water on the renal functions of 10 patients

\begin{tabular}{|c|c|c|c|c|c|c|c|c|c|c|}
\hline 2. & son: & 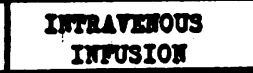 & B.P. & P.ab & 0.0. & $\boldsymbol{\sigma}$ & Con & $\pi$ & C. & 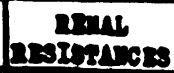 \\
\hline PAI & $\begin{array}{l}0-15 \\
41 \\
78 \\
112 \\
150 \\
185 \\
220 \\
255 \\
290 \\
327 \\
362 \\
396\end{array}$ & $\begin{array}{c}\text { Oluoose } \\
\text { rater (4mi/nin) } \\
n \\
n \\
\text { elnoose ot } \\
\text { oluoose } \\
n \\
n \\
n \\
n \\
n\end{array}$ & $\begin{array}{l}120 / 70 \\
100 / 60 \\
110 / 70 \\
100 / 60 \\
110 / 60 \\
100 / 70\end{array}$ & $\begin{array}{r}66 \\
102 \\
138 \\
179 \\
243 \\
105 \\
93 \\
70 \\
58 \\
42\end{array}$ & $\begin{array}{l}\dot{0} \\
\dot{0} \\
+ \\
+ \\
+ \\
+ \\
+ \\
+\end{array}$ & $\begin{array}{c}12.00 \\
13.25 \\
6.49 \\
1005 \\
\text { nos.21. } \\
0.14 \\
0.043 \\
4.00 \\
9.72 \\
8.29 \\
7.85 \\
6.61\end{array}$ & $\begin{array}{r}1810 \\
71 \\
86 \\
157 \\
146 \\
144 \\
185 \\
119\end{array}$ & $\begin{array}{l}\text { ur } 12 \\
.35 \\
.32 \\
.30 \\
.30 \\
.30 \\
.33 \\
.18\end{array}$ & $\begin{array}{l}639 \\
629 \\
422 \\
\\
202 \\
269 \\
528 \\
492 \\
495 \\
566 \\
661\end{array}$ & $\begin{array}{l}6900 \\
6150 \\
9200 \\
\\
200 \text { noxt } \\
20200 \\
14350 \\
6850 \\
7600 \\
7800 \\
6800 \\
5050\end{array}$ \\
\hline PAT & $\begin{array}{c}0-17 \\
34 \\
54 \\
78 \\
101 \\
123 \\
154 \\
178 \\
197 \\
221 \\
244 \\
266\end{array}$ & 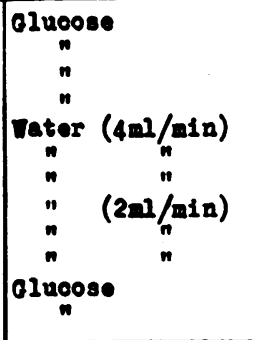 & $\begin{array}{l}125 / 70 \\
130 / 75 \\
130 / 85 \\
130 / 80 \\
150 / 80\end{array}$ & $\begin{array}{r}2 \\
17 \\
66 \\
131 \\
133 \\
129 \\
128 \\
124 \\
101\end{array}$ & $\begin{array}{l}- \\
\overline{-} \\
\overline{-} \\
- \\
+ \\
+ \\
+ \\
+\end{array}$ & $\begin{array}{r}4.53 \\
9.55 \\
7.00 \\
8.70 \\
3.63 \\
0.97 \\
\text { nogi18 } \\
0.33 \\
0.79 \\
2.70 \\
5.19\end{array}$ & $\begin{array}{r}91 \\
91 \\
89 \\
79 \\
56 \\
29 \\
1310 \\
69 \\
93 \\
95 \\
71\end{array}$ & \begin{tabular}{|l|}
.16 \\
.18 \\
.18 \\
.15 \\
.18 \\
.15 \\
0.15 \\
.21 \\
.22 \\
.20 \\
.21
\end{tabular} & $\begin{array}{l}573 \\
502 \\
494 \\
510 \\
318 \\
195 \\
40,0 \\
400 \\
439 \\
467 \\
334\end{array}$ & $\begin{array}{l}8150 \\
9550 \\
9900 \\
10100 \\
15800 \\
26950 \\
13750\end{array}$ \\
\hline Ex & $\begin{array}{c}0-17 \\
36 \\
54 \\
79 \\
102 \\
130 \\
146 \\
164 \\
187 \\
210\end{array}$ & 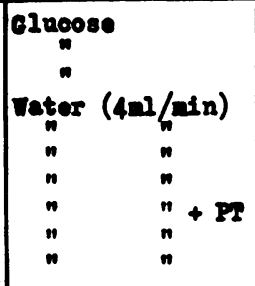 & $\begin{array}{l}170 / 105 \\
160 / 105 \\
180 / 110 \\
170 / 100 \\
180 / 105\end{array}$ & $\begin{array}{r}10 \\
16 \\
10 \\
16 \\
49 \\
81 \\
101 \\
115 \\
122 \\
140\end{array}$ & $\begin{array}{l}= \\
= \\
= \\
+ \\
+ \\
+\end{array}$ & $\begin{array}{r}3.47 \\
6.31 \\
7.94 \\
7.60 \\
4.96 \\
2.07 \\
0.88 \\
3.33 \\
10.88 \\
7.48\end{array}$ & $\begin{array}{r}103 \\
240 \\
140 \\
93 \\
97 \\
76 \\
67 \\
156 \\
87 \\
91\end{array}$ & $\begin{array}{l}.28 \\
.35 \\
.37 \\
.31 \\
.30 \\
.28 \\
.34 \\
.31 \\
.25 \\
.25\end{array}$ & $\begin{array}{l}368 \\
395 \\
379 \\
300 \\
319 \\
276 \\
195 \\
498 \\
353 \\
362\end{array}$ & $\begin{array}{l}15450 \\
14150 \\
14450 \\
21100 \\
19900 \\
21750 \\
32500 \\
12750 \\
15050 \\
16300\end{array}$ \\
\hline 12 & $\begin{array}{r}0-19 \\
43 \\
67 \\
88 \\
110 \\
137 \\
159 \\
175 \\
207 \\
236 \\
267\end{array}$ & 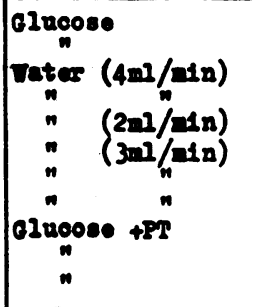 & $\begin{array}{l}140 / 90 \\
140 / 90 \\
140 / 90 \\
140 / 90 \\
140 / 90\end{array}$ & $\begin{array}{r}7 \\
2 \\
65 \\
135 \\
151 \\
170 \\
192 \\
180 \\
165 \\
140\end{array}$ & $\begin{array}{l}- \\
= \\
- \\
+ \\
+ \\
+ \\
+ \\
+ \\
+\end{array}$ & $\begin{array}{l}5.68 \\
6.00 \\
2.37 \\
0.62 \\
0.77 \\
1.22 \\
0.50 \\
0.031 \\
4.35 \\
3.45 \\
0.97\end{array}$ & $\begin{array}{r}75 \\
88 \\
72 \\
95 \\
170 \\
126 \\
94 \\
62 \\
174 \\
117 \\
155\end{array}$ & $\begin{array}{l}.15 \\
.17 \\
.23 \\
.34 \\
.37 \\
.36 \\
.48 \\
.46 \\
.25 \\
.26 \\
.35\end{array}$ & $\begin{array}{l}510 \\
504 \\
312 \\
277 \\
381 \\
351 \\
198 \\
136 \\
658 \\
452 \\
445\end{array}$ & $\begin{array}{r}9000 \\
9100 \\
14650 \\
16500 \\
12000 \\
13000 \\
23100 \\
39600 \\
6950 \\
10100 \\
10300\end{array}$ \\
\hline $\sin$ & $\begin{array}{c}0-18 \\
35 \\
56 \\
84 \\
206 \\
128 \\
252 \\
174 \\
198 \\
222 \\
242\end{array}$ & 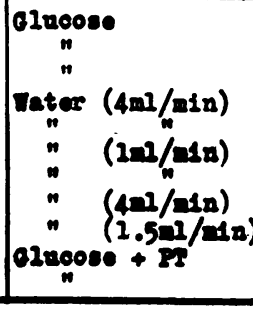 & $90 / 60$ & $\begin{array}{r}5 \\
8 \\
13 \\
46 \\
51 \\
57 \\
67 \\
70 \\
61 \\
52 \\
\end{array}$ & $\begin{array}{l}\overline{-} \\
\overline{-} \\
\overline{-} \\
\overline{-} \\
\overline{+} \\
+\end{array}$ & $\begin{array}{l}3.72 \\
9.17 \\
9.71 \\
8.65 \\
3.63 \\
0.36 \\
0.46 \\
n 0.416 \\
0.33 \\
2.38 \\
2.55\end{array}$ & $\begin{array}{r}105 \\
131 \\
84 \\
70 \\
54 \\
52 \\
64 \\
1810 \\
59 \\
99 \\
98\end{array}$ & $\begin{array}{l}.18 \\
.16 \\
.14 \\
.13 \\
.16 \\
.15 \\
.16 \\
0.18 \\
.19 \\
.14 \\
.13\end{array}$ & $\begin{array}{l}573 \\
798 \\
596 \\
528 \\
332 \\
341 \\
\end{array}$ & \begin{tabular}{|c}
6600 \\
450 \\
6000 \\
8750 \\
20100 \\
9800 \\
8800 \\
ded to \\
11000 \\
4500 \\
4500
\end{tabular} \\
\hline
\end{tabular}

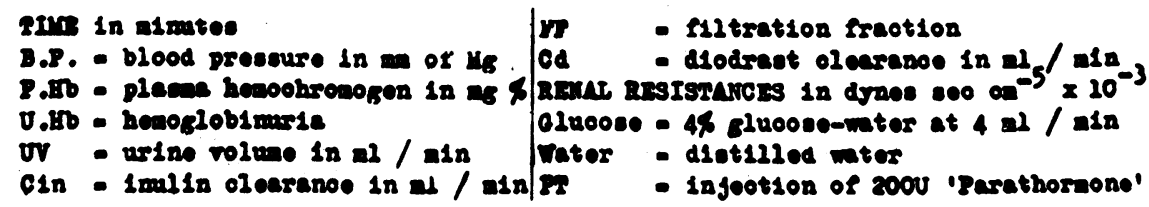


RENAL FUNCTION IN INTRAVASCULAR HEMOLYSIS

TABLE II Continued

\begin{tabular}{|c|c|c|c|c|c|c|c|c|c|c|}
\hline BDS. & Tns & $\begin{array}{l}\text { Ingravenous } \\
\text { InINSIOI }\end{array}$ & B.P. & $.8 b$ & U.50 & UT & $c_{1 n}$ & $\boldsymbol{H}$ & $c_{d}$ & $\begin{array}{c}2+11 \\
\text { arseres }\end{array}$ \\
\hline NEE & $\begin{array}{c}0-22 \\
49 \\
72 \\
98 \\
120 \\
244 \\
166 \\
188 \\
211 \\
234 \\
247\end{array}$ & 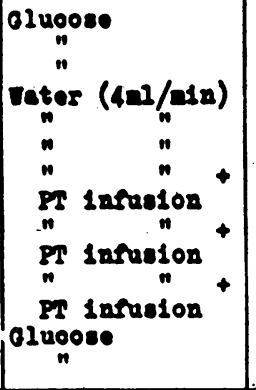 & $\begin{array}{l}205 / 70 \\
215 / 80 \\
120 / 80 \\
120 / 70 \\
105 / 60 \\
\\
110 / 70 \\
110 / 70 \\
120 / 70\end{array}$ & $\begin{array}{r}5 \\
6 \\
6 \\
17 \\
42\end{array}$ & $\begin{array}{l}- \\
\dot{-} \\
\dot{-} \\
- \\
+ \\
+ \\
+\end{array}$ & $\begin{array}{c}2.36 \\
0.70 \\
0.06 \\
0.58 \\
00.118 \\
0.33 \\
5.56 \\
1.41 \\
0.48 \\
0.22 \\
0.46\end{array}$ & $\begin{array}{r}129 \\
70 \\
84 \\
73 \\
1810 \\
53 \\
331 \\
206 \\
75 \\
67 \\
155\end{array}$ & $\begin{array}{l}.26 \\
.12 \\
.21 \\
.26 \\
.16 \\
.16 \\
.25 \\
.20 \\
.12 \\
.15 \\
.12\end{array}$ & $\begin{array}{r}496 \\
581 \\
403 \\
466 \\
203 \\
325 \\
2220 \\
1056 \\
650 \\
443 \\
1315\end{array}$ & $\begin{array}{c}8900 \\
8450 \\
22450 \\
9700 \\
4000 x t \\
23300 \\
1870 \\
4100 \\
6160 \\
10200 \\
3430\end{array}$ \\
\hline Fo & $\begin{array}{c}0-16 \\
34 \\
54 \\
77 \\
95 \\
110 \\
130 \\
156 \\
168 \\
185 \\
206 \\
227 \\
249\end{array}$ & 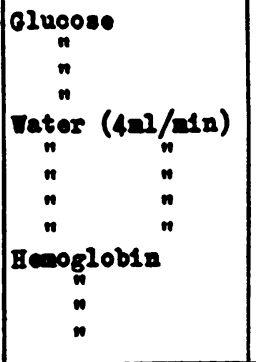 & $\begin{array}{l}105 / 75 \\
125 / 75 \\
110 / 75 \\
115 / 75\end{array}$ & $\begin{array}{r}5 \\
3 \\
4 \\
4 \\
45 \\
72 \\
133 \\
166 \\
197 \\
226 \\
212 \\
218 \\
226\end{array}$ & $\begin{array}{l}- \\
\dot{0} \\
\dot{-} \\
\dot{-} \\
\dot{1} \\
+ \\
+ \\
+\end{array}$ & $\begin{array}{r}8.87 \\
12.75 \\
15.10 \\
16.33 \\
14.330 \\
9.86 \\
4.15 \\
1.17 \\
0.25 \\
0.94 \\
3.33 \\
7.24 \\
10.61\end{array}$ & $\begin{array}{r}104 \\
107 \\
93 \\
90 \\
106 \\
91 \\
79 \\
92 \\
78 \\
101 \\
117 \\
107 \\
149\end{array}$ & $\begin{array}{l}.18 \\
.22 \\
.18 \\
.17 \\
.23 \\
.19 \\
.21 \\
.24 \\
.32 \\
.48 \\
.28 \\
.35 \\
.47\end{array}$ & $\begin{array}{l}570 \\
492 \\
528 \\
537 \\
463 \\
472 \\
379 \\
379 \\
243 \\
211 \\
414 \\
310 \\
317\end{array}$ & $\begin{array}{r}6700 \\
7700 \\
7200 \\
7100 \\
8200 \\
8050 \\
12250 \\
17250 \\
16500 \\
18000 \\
2450 \\
12800 \\
12700\end{array}$ \\
\hline QUE & $\begin{array}{l}0-15 \\
29 \\
52 \\
78 \\
108 \\
133 \\
158 \\
183 \\
209 \\
234 \\
260 \\
285\end{array}$ & 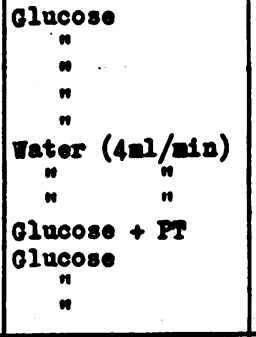 & $\begin{array}{l}125 / 85 \\
120 / 80 \\
130 / 90 \\
125 / 85 \\
105 / 80 \\
105 / 75 \\
110 / 80 \\
120 / 80 \\
110 / 80 \\
120 / 80\end{array}$ & $\begin{array}{r}8 \\
10 \\
5 \\
5 \\
9 \\
23 \\
44 \\
63 \\
73 \\
70 \\
55 \\
54 \\
\end{array}$ & $\begin{array}{l}= \\
= \\
\bar{z} \\
= \\
= \\
=\end{array}$ & $\begin{array}{l}1.33 \\
0.86 \\
1.39 \\
2.11 \\
1.50 \\
0.76 \\
1.12 \\
2.80 \\
3.38 \\
4.68 \\
6.35 \\
7.00\end{array}$ & $\begin{array}{r}124 \\
136 \\
131 \\
126 \\
76 \\
85 \\
212 \\
99 \\
98 \\
100 \\
112 \\
114 \\
\end{array}$ & $\begin{array}{l}.23 \\
.27 \\
.18 \\
.17 \\
.12 \\
.14 \\
.18 \\
.15 \\
.12 \\
.12 \\
.13 \\
.15\end{array}$ & $\begin{array}{l}539 \\
503 \\
716 \\
780 \\
646 \\
607 \\
630 \\
652 \\
800 \\
882 \\
844 \\
738 \\
\end{array}$ & $\begin{array}{r}9800 \\
10000 \\
7750 \\
6750 \\
7200 \\
7450 \\
7400 \\
7300 \\
6150 \\
5700 \\
5650 \\
6800 \\
\end{array}$ \\
\hline SOF & $\begin{array}{c}0-15 \\
34 \\
59 \\
85 \\
109 \\
130 \\
154 \\
175 \\
197 \\
219 \\
242 \\
266\end{array}$ & 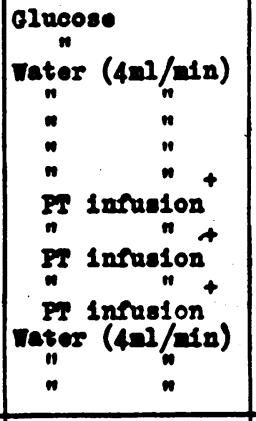 & $\begin{array}{l}110 / 90 \\
120 / 90 \\
105 / 85 \\
120 / 95 \\
120 / 95 \\
125 / 95 \\
120 / 90 \\
125 / 95 \\
130 / 80 \\
120 / 80 \\
120 / 85 \\
115 / 85 \\
\end{array}$ & $\begin{array}{r}3 \\
25 \\
90 \\
104 \\
125\end{array}$ & $\begin{array}{l}- \\
= \\
- \\
+ \\
+ \\
+ \\
+ \\
+ \\
+ \\
+\end{array}$ & $\begin{array}{r}2.40 \\
1.58 \\
8.00 \\
24.30 \\
6.58 \\
7.15 \\
10.82 \\
16.19 \\
11.37 \\
8.18 \\
2.17 \\
1.13\end{array}$ & $\begin{array}{r}82 \\
102 \\
127 \\
112 \\
110 \\
83 \\
96 \\
92 \\
85 \\
103 \\
77 \\
101 \\
\end{array}$ & $\begin{array}{l}.20 \\
.20 \\
.16 \\
.17 \\
.22 \\
.22 \\
.14 \\
.11 \\
.12 \\
.13 \\
.12 \\
.16\end{array}$ & $\begin{array}{l}407 \\
503 \\
775 \\
651 \\
505 \\
386 \\
696 \\
823 \\
711 \\
810 \\
620 \\
620\end{array}$ & $\begin{array}{r}12100 \\
9800 \\
6050 \\
8150 \\
10500 \\
13750 \\
7450 \\
6450 \\
7300 \\
6100 \\
8150 \\
7950\end{array}$ \\
\hline 806 & $\begin{array}{c}0-20 \\
43 \\
67 \\
90 \\
115 \\
241 \\
163 \\
180 \\
205 \\
231 \\
258 \\
203 \\
\end{array}$ & 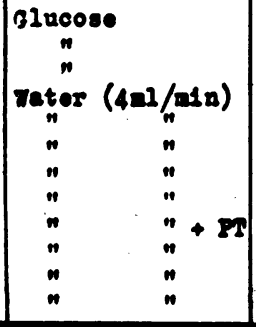 & $\begin{array}{l}225 / 65 \\
225 / 70\end{array}$ & $\begin{array}{r}3 \\
7 \\
3 \\
15 \\
62 \\
77 \\
88 \\
206 \\
103 \\
111 \\
114 \\
124\end{array}$ & E & $\begin{array}{r}3.80 \\
1.65 \\
1.96 \\
3.57 \\
4.32 \\
2.31 \\
2.41 \\
2.47 \\
13.90 \\
12.70 \\
12.28 \\
10.20\end{array}$ & $\begin{array}{r}50 \\
72 \\
79 \\
56 \\
66 \\
88 \\
89 \\
77 \\
120 \\
92 \\
107 \\
98\end{array}$ & $\begin{array}{l}.24 \\
.15 \\
.18 \\
.21 \\
.24 \\
.17 \\
.17 \\
.28 \\
.16 \\
.19 \\
.24 \\
.27\end{array}$ & $\begin{array}{l}363 \\
466 \\
430 \\
530 \\
468 \\
530 \\
540 \\
425 \\
735 \\
475 \\
440 \\
362\end{array}$ & $\begin{array}{r}11250 \\
8750 \\
9500 \\
7700 \\
8700 \\
7700 \\
7550 \\
9600 \\
5550 \\
8600 \\
9250 \\
21600\end{array}$ \\
\hline
\end{tabular}


fusion of water and this reduction started as soon as urine flow began to decrease that is, when hemolysis began.

Inulin clearances: A significant direct correlation developed between the rate of urine flow and inulin clearance during the infusion of distilled water though it was not demonstrable during the control periods. Correlation coefficients were derived in the same manner as for Diodrast clearances and were similar. Prior to the distilled water infusion the correlation coefficient was low and insignificant $(r=0.14, \mathrm{n}=30, \mathrm{P}=>0.1)$ but during the infusion of distilled water the correlation coefficient was higher and highly significant $(\mathrm{r}=0.41, \mathrm{n}=41, \mathrm{P}=<0.01>0.001)$.

The correlation between GFR and urine flow was not as close as that between urine flow and RPF (Table II, and Figure 2).

Filtration fraction: This function rose in four patients and was considerably increased during the period of maximal oliguria. The maximum figures in the control periods were $0.23,0.18,0.17$ and 0.22 but in the experimental periods 0.35 , $0.21,0.48$, and 0.32 respectively.

Calculated renal vascular resistances: These resistances were increased in all patients developing oliguria and were considered to indicate renal vasoconstriction.

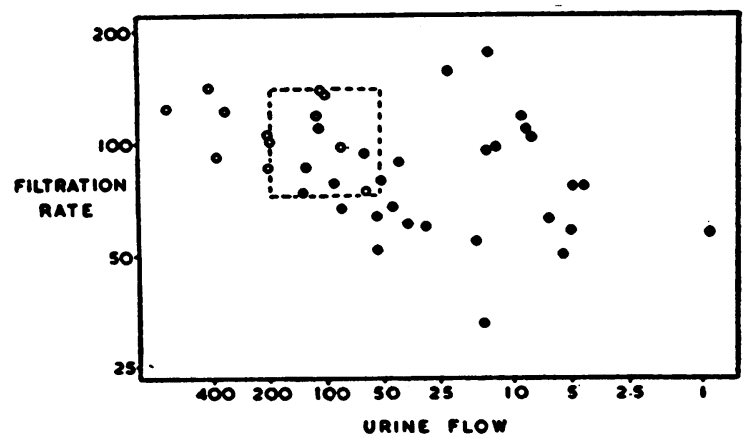

Fig. 2. Relationship between the Change in Glomerular Filtration Rate ( $C_{\text {ix }}$ ) and the Change in Urine Flow in 10 Patients during the IntraveNous INFusion of Distilled WATER

$\mathrm{C}_{\mathrm{IN}}$ and UV are both plotted as percentages of the mean control values ( 100 per cent) for each patient. The area included by the dotted lines represents the mean $\pm 2 \sigma$ of all the control $C_{I N}$ and $U V$ values. Solid circles represent the data from the seven oliguric patients, the closed circles the data from the three patients without oliguria.
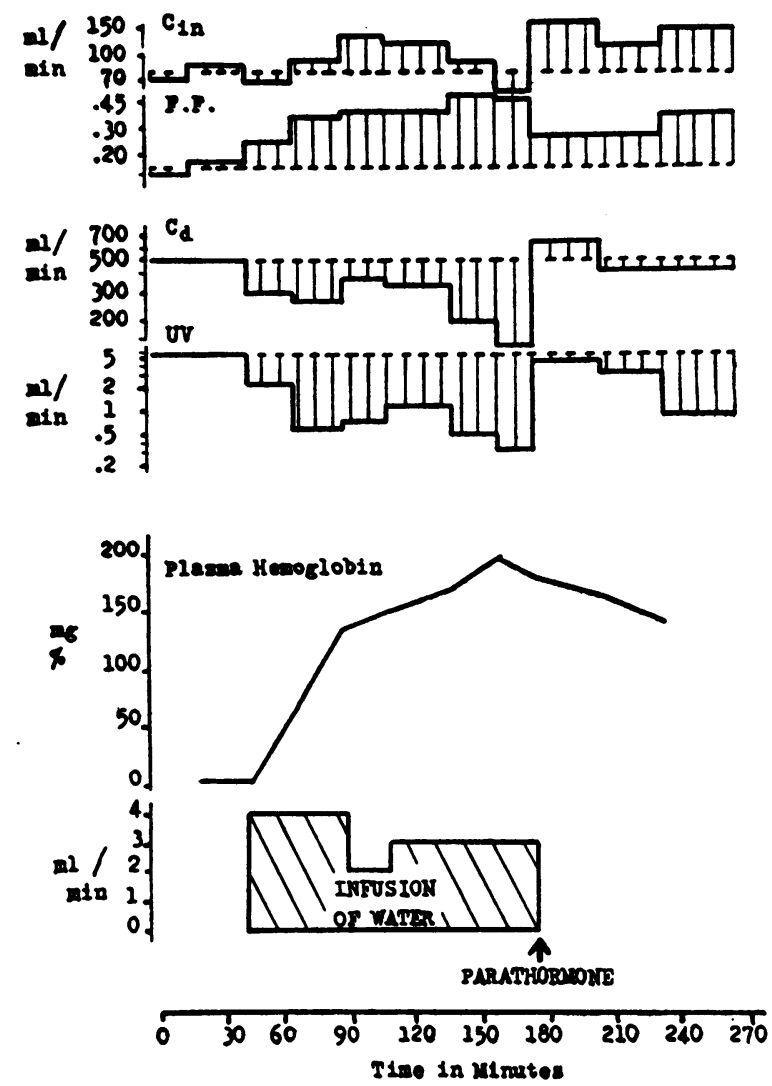

Fig. 3. Changes in Renal Function and Plasma HEMOCHROMogen Concentration dURING AND AFTER the Infusion of Distilled Water (SubJect FER)

Alterations in renal function bear an inverse relation to the rate of water infusion and are promptly restored towards normal by the injection of 200 units of Parathormone intravenously.

Plasma and urine hemochromogens: The plasma hemochromogen concentration bore no constant relation to the development of oliguria, the levels were no higher in the patients developing oliguria than those who did not. The amount of hemolysis depended mainly on the size of the vein receiving the infusion and on the blood flow through it as the infusions of water were usually given at the same rate, $4 \mathrm{ml}$. per minute. In general, the smaller the vein used the greater the hemolysis. The highest plasma hemochromogen concentrations were from 70 to $226 \mathrm{mg}$. per cent with a mean of $142 \mathrm{mg}$. per cent.

The rate of infusion of water appeared to be of greater importance in producing changes in renal function than the plasma hemochromogen concentration, for decreasing the rate of water infusion 

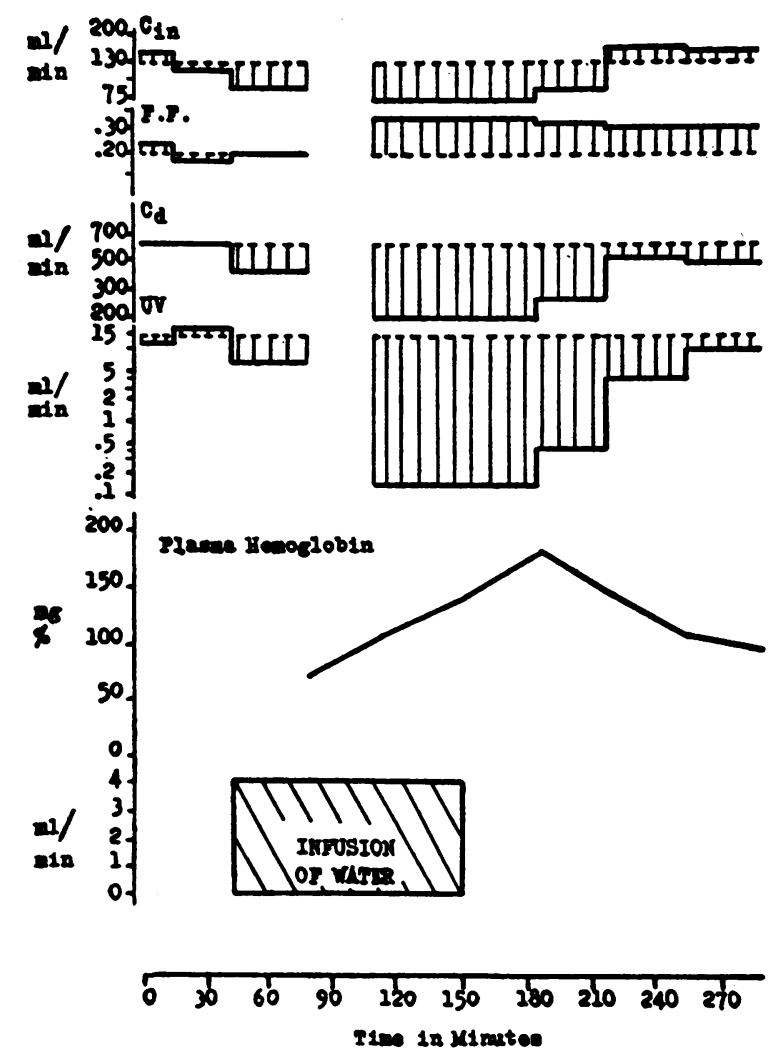

Fig. 4. Changes in Renal Function and Plasma Hemochromogen Concentration dURING AND AFTER the Infusion of Distilled Water (SUbject PAY)

resulted in a prompt increase in urine flow and Diodrast clearance (PAT, FER, SMI in Table II and Figure 3). Increasing the rate of water infusion produced the reverse effects. The changes in plasma hemochromogen concentration after it became elevated were quite minor in degree and only once did the concentration fall after a temporary decrease in the rate of infusion of water.

Oliguria was accompanied or followed by hemoglobinuria in six of the seven patients developing concomitant decreased renal plasma flow, but hemoglobinuria was observed in the absence of oliguria or diminished renal blood flow (SOF in Table I). Hemoglobinuria usually appeared when the plasma concentration was 100 to $150 \mathrm{mg}$. per $100 \mathrm{ml}$.

Changes after stopping the distilled water infusions: In the oliguric patients urine flow, renal plasma flow and filtration rate increased in the first period after stopping the distilled water infusion and then returned toward, or to, the con- trol levels (PAY and PAT in Table II, Figure 4). This reversal was significant within 20 minutes. A similar effect was observed when a solution of the patient's own stroma free hemoglobin ( 0.7 per cent) in 0.85 per cent saline was substituted for distilled water (FLO in Table II, Figure 5). This reversal took place in the presence of unchanged or increased plasma hemochromogen concentrations and often in the presence of increased hemoglobinuria.

Effects of Parathormone: The intravenous injection of Parathormone solution produced a prompt diuresis, a marked increase in Diodrast clearance and a fall in filtration fraction in every patient who was given it whether they had oliguria or not (ELL, FER, SMI, NEE, QUE, SOF, HUG in Table II, Figures 3 and 6). In five of these seven patients inulin clearances increased considerably but in two (QUE, SOF)

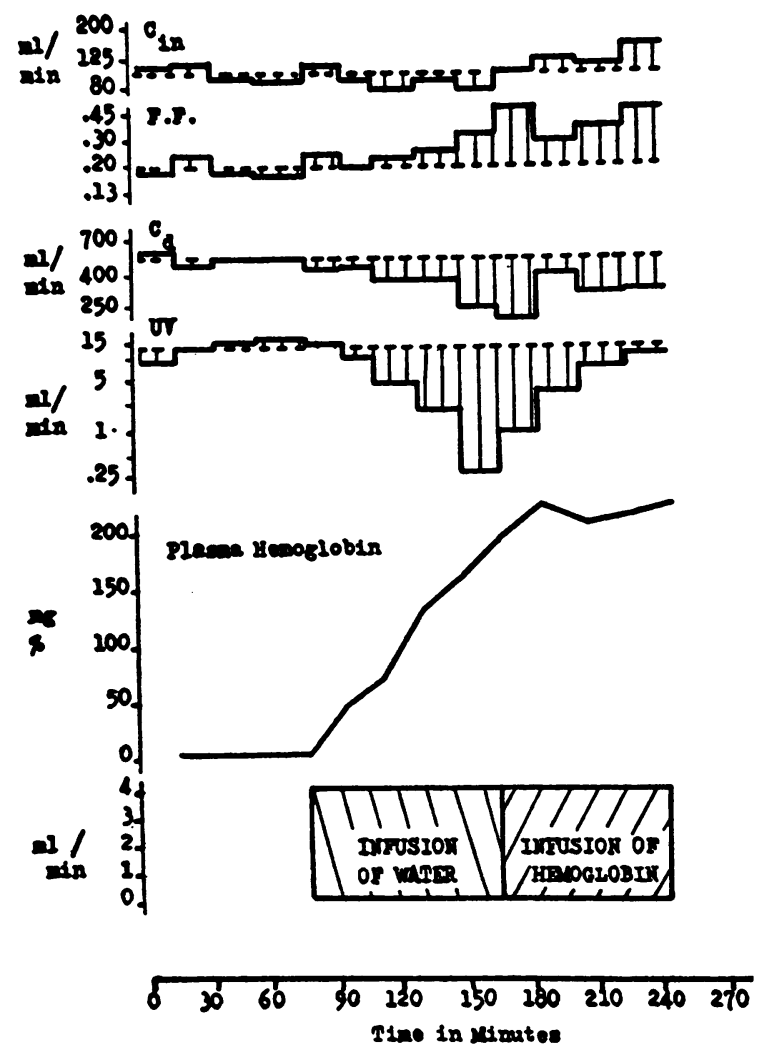

Fig. 5. Changes in Renal Function and Plasma Hemochromogen Concentration during the Infusion OF Distilled Water aNd dURING the INFUSION OF a Solution of the Patient's Own Hemoglobin (SubJECT FLO) 


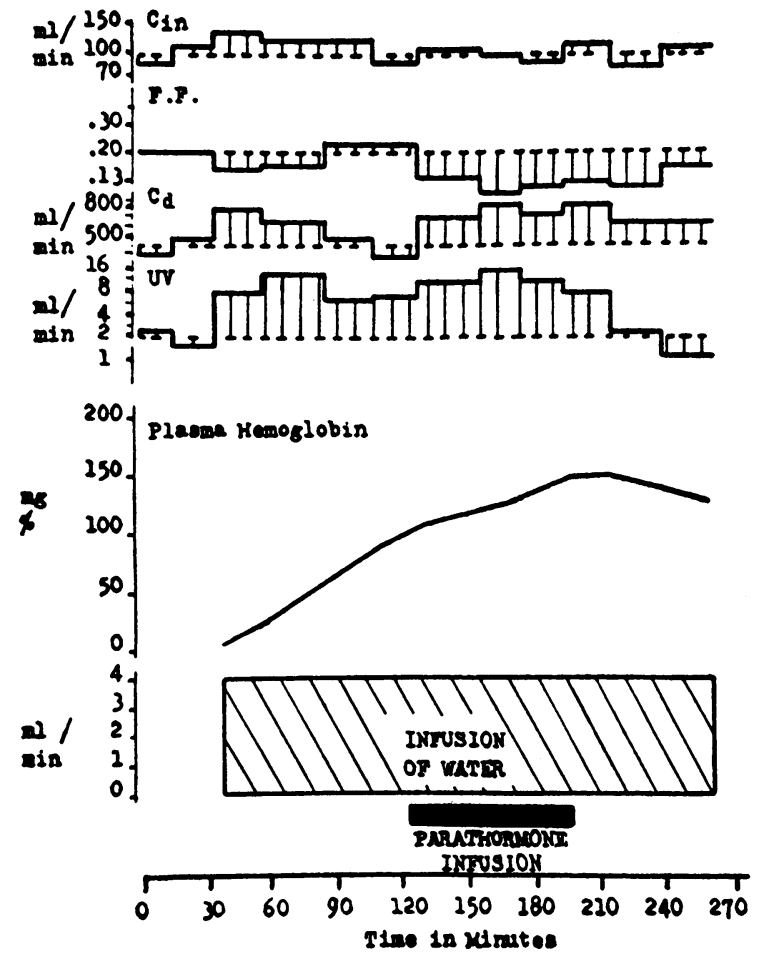

Fig. 6. Changes in Renal Function, and Plasma HEMOCHROMOgEN CONCENTRATION DURING THE INFUsion of Distilled Water (Subject SOF).

Intravenous injection of 200 units of Parathormone in $100 \mathrm{ml}$. saline produce prompt changes in $C_{D}$ and $U V$.

were unchanged and neither of these two patients had evidence of significant renal vasoconstriction or oliguria. These reactions were typically those of intense renal hyperemia and were unaccompanied by systemic changes. No patient had evidence of abnormal sensitivity to the intradermal injection of Parathormone prior to the intravenous injection and the renal effects appeared to be unrelated to any effect on phosphate reabsorption.

\section{DISCUSSION}

One of the most striking changes in renal function was the occurrence of a diminished urine flow and a diminished Diodrast clearance in 7 of the 10 patients during the infusion of distilled water. A diminished Diodrast clearance was considered to indicate decreased renal plasma flow and this, in turn, to indicate renal vasoconstriction. Renal vasoconstriction did not appear to be a part of gross generalized vasoconstriction in our patients for there were no significant changes in arterial blood pressure or pulse rates. Miller and McDonald (6), on the other hand, recorded raised blood pressures in normal subjects during similar experiments. A decreased renal plasma flow was not only observed in the patients with profound oliguria but also in three patients whose minimum urine flows were $0.25,0.31$, and $0.88 \mathrm{ml}$. per minute, respectively. A statistically highly significant direct correlation between urine flow and renal blood flow was found when the data on all $10 \mathrm{pa}$ tients were considered though considerable variation was observed in the data from individual patients. Though it has been suggested that urine flow may be influenced by renal blood flow to a greater extent than is usually considered (14) significant correlations have not been recorded unless there has been a great reduction in urine flow. Urine flow does vary with renal blood flow in the experimental animal if the renal artery is temporarily occluded (15), or if blood flow is reduced though the perfusion pressure be kept constant (16), or if the kidney is previously subjected to 5 to 20 minutes of ischemia (17). The renal functional changes in our patients resembled those of post-ischemic or perfused kidneys.

Changes in the rate of infusion of distilled water were promptly followed by inverse changes in the rates of urine flow and renal blood flow in oliguric patients. Renal function returned toward normal when the distilled water infusion was stopped and 4 per cent glucose in water substituted for it.

The effects of distilled water did not appear to be due to impurities since the same water was used for making up all the intravenous solutions given to these patients in the three-year period during which the studies were made. Some patients did develop pyrexial reactions but there was no correlation between these reactions and the development of oliguria or diuresis.

Intravenous infusion of distilled water led to hemolysis and some product of hemolysis may have caused renal vasoconstriction and oliguria. Hemoglobin and its degradation products, unknown vasoconstrictive substances and erythrocyte stroma have all been suggested as proximate causes of acute renal failure.

It is difficult to attribute decreased renal blood flow and oliguria directly to the effects of raised plasma hemoglobin levels. One patient had a diuresis and increasing renal blood flow, in spite of a rising plasma hemochromogen level, when a 0.7 per cent solution of his own hemoglobin in 0.85 per cent saline was substituted for distilled water. 
The appearance of renal vasoconstriction and oliguria appeared not to depend on the plasma hemochromogen concentration nor did urine flow vary inversely with it except in a very general way. Hemoglobin solutions have been infused into convalescent patients and patients with renal disease to determine glomerular permeability and, though plasma hemoglobin levels of $500 \mathrm{mg}$. per cent were reached, no instance of oliguria or anuria was recorded (18). Badenoch and Darmady (19) concluded that hemoglobin was nephrotoxic only if a critical degree of renal damage had previously been achieved. Only two groups of workers have regularly produced renal vasoconstriction by the infusion of hemoglobin solutions.

The importance of tubular necrosis from nephrotoxins and of disruption of tubules (tubulorrhexis) from focal cortical ischemia (the ischemuric episode), in the pathogenesis of acute renal failure has been stressed by Oliver, MacDowell, and Tracy (20) in their excellent paper. They have discussed the importance of combinations of these factors and point out that many causes lead to the single entity of acute renal failure. It has been suggested that tubular damage may lead to unselective back diffusion of glomerular filtrate. Such effects from hemoglobinemia or distilled water cannot have been important in our patients for the reasons set out in the discussion on the validity of the clearances and because the changes in renal function were rapidly reversible.

The intravenous injection of hematin into the dog induces changes in renal function closely resembling those observed in our patients (21). In man hematin rapidly combines with serum albumin to form methemalbumin but this does not occur in the dog (22). Methemalbumin was identified in the plasma of our patients by spectrophotometric and electrophoretic methods (23) and was found in the urine of some of them (24). As methemalbumin is regularly found in the plasma of all patients who have elevated plasma hemoglobin levels the arguments used in the discussion of the role of hemoglobin apply also to methemalbumin. There was no evidence that methemalbumin acted as a renal vasoconstrictive agent in our patients.

Amberson, Jennings, and Rhode (5) attributed the development of acute renal failure after the infusion of hemoglobin solutions in two of their subjects, to some unknown soluble vasoconstric- tive agent. Such a substance may be liberated during hemolysis but it must be relatively unstable for it appeared to be lost in a few hours at $4^{\circ} \mathrm{C}$. during the preparation of our hemoglobin solution and most of those used by other workers. Its presence cannot be denied.

Erythrocyte stroma has been suggested as a major factor in the genesis of reactions to intravascular hemolysis but Maluf (25) failed to demonstrate differences between the effects of freshly lysed red cells and of hemoglobin solutions given to dogs. On the other hand the intravenous infusion of homologous stroma into the rat (26) or mouse (27) is quickly lethal and the infusion of stroma into the dog has been reported to induce cutaneous petechiae (28). Small "foreign bodies" could induce local renal vasospasm and any vasodilator might promptly reverse their effect.

The intravenous injection of Parathormone resulted in a prompt diuresis and renal vasodilatation in every patient to whom it was given. The exact degree of renal hyperemia could not be assessed as there was some "washing-out" of inulin and Diodrast from the oliguric kidneys. These changes occurred regardless of the presence of oliguria and renal vasoconstriction and were usually maintained for 40 to 60 minutes.

The effects of Parathormone were not found to be related to any specific effect of the hormone on the tubular reabsorption of phosphate and could be elicited equally well with an autoclaved preparation. The effects appeared to be of a non-specific protein nature. It is important to consider this renal vasodilator effect in the study of the effects of Parathormone on the renal clearance of phosphate.

The data reported here indicate that some patients receiving intravenous infusions of distilled water, and having intravascular hemolysis from them, develop reversible renal vasoconstriction and oliguria without clinical evidence of systemic cardiovascular changes. Profound oliguria did not indicate that structural changes had occurred in the renal tubule cells and that function could be restored only after regeneration. If this type of renal response was due to intravascular hemolysis, and not to the infusion of distilled water as such, it could be a determining factor in the genesis of acute renal failure. Renal vasoconstriction from hemolysis could be converted to severe renal ischemia by mild to moderate shock induced 
by the reactions to mis-matched blood transfusion, $\mathrm{Cl}$. Welchii infections, or blackwater fever. This could provide a partial explanation for the irregular incidence of acute renal failure after intravascular hemolysis.

\section{SUMMARY}

1. Intravascular hemolysis has been induced in 10 patients by the infusion of distilled water into a small peripheral vein while renal function was studied.

2. Urine flow became directly correlated with renal plasma flow (Diodrast clearance).

3. Profound oliguria and marked renal vasoconstriction developed in seven of the patients but both rapidly disappeared when the infusion of distilled water was discontinued.

4. Oliguria and renal vasoconstriction could be reversed rapidly by the intravenous injection of Parathormone which caused renal hyperemia.

\section{REFERENCES}

1. Rosoff, C. B., and Walter, C. W., The controlled laboratory production of hemoglobinuric nephrosis. Ann. Surg., 1952, 135, 324

2. Mason, A. D., and Mueller, C. B., Experimental observations on the role played by anaphylaxis in the development of renal disease following the infusion of mismatched blood. Science, 1952, 116, 526.

3. Landsteiner, E. K., and Finch, C. A., Hemoglobinemia accompanying transurethral resection of the prostate. New England J. Med., 1947, 237, 310.

4. Voris, H. C., Subdural hematoma. J.A.M.A., 1946, 132, 686.

5. Amberson, W. R., Jennings, J. J., and Rhode, C. M., Clinical experience with hemoglobin-saline solutions. J. Applied Physiol., 1949, 1, 469. (Quoted by Smith, H. W., The Kidney, Oxford University Press, New York, 1951, p. 793.)

6. Miller, J. H., and McDonald, R. K., The effect of hemoglobin on renal function in the human. $\mathrm{J}$. Clin. Invest., 1951, 30, 1033.

7. Goldring, W., and Chasis, H., Hypertension and hypertensive disease, The Commonwealth Fund, New York, 1944.

8. Little, J. M., A modified diphenylamine procedure for the determination of inulin. J. Biol. Chem., 1949, $180,747$.

9. Alpert, L. K., A rapid method for the determination of Diodrast-iodine in blood and urine. Bull. Johns Hopkins Hosp., 1941, 68, 522.

10! Bing, F. C., and Baker, R. W., The determination of hemoglobin in minute amounts of blood by Wu's method. J. Biol. Chem., 1931, 92, 589.
11. Hunter, F. T., Grove-Rasmussen, M., and Soutter, L., A spectrophotometric method for quantitating hemoglobin in plasma or serum. Am. J. Clin. Path., 1950, $20,429$.

12. Unpublished data.

13. Phillips, R. A., Dole, V. P., Hamilton, P. B., Emerson, K., Jr., Archibald, R. M., and Van Slyke, D. D., Effects of acute hemorrhagic and traumatic shock on the renal function of dogs. Am. J. Physiol., $1946,145,314$.

14. Hinkle, L. E., Jr., Edwards, C. J., and Wolf, S., The occurrence of diuresis in humans in stressful situations and its possible relation to the diuresis of early starvation. J. Clin. Invest., 1951, 30, 809.

15. Hermann: Sitzungsb. d. kaiserliche Akad. d. Wissensch. zu Wien 1862, 45, Abth. II. 317. (Quoted by Richards and Plant [16].)

16. Richards, A. N., and Plant, O. H., Urine formation in the perfused kidney. The influence of alterations in renal blood pressure on the amount and composition of urine. Am. J. Physiol., 1922, 59, 144.

17. Selkurt, E. E., Comparison of renal clearances with direct renal blood flow under control conditions and following renal ischemia. Am. J. Physiol., 1946, 145, 376.

18. Brandt, J. L., Frank, R., and Lichtman, H. C., Normal hemoglobin clearances in chronic proteinuria. Proc. Soc. Exper. Biol. \& Med., 1950, 74, 863.

19. Badenoch, A. W., and Darmady, E. M., The effect of stroma-free haemoglobin on ischaemic kidney of the rabbit. Brit. J. Exper. Path., 1948, 29, 215.

20. Oliver, J., MacDowell, M., and Tracy, A., The pathogenesis of acute renal failure associated with traumatic and toxic injury. Renal ischemia, nephrotoxic damage and the ischemuric episode. J. Clin. Invest., 1951, 30, 1307.

21. Corcoran, A. C., and Page, I. H., Renal damage from ferroheme pigments myoglobin, hemoglobin, hematin. Texas Rep. Biol. \& Med., 1945, 3, 528. (Quoted by Smith, H. W., The Kidney, New York, Oxford University Press, 1951, p. 793.)

22. Fairley, N. H., Methaemalbumin. Part I. Clinical aspects. Part II. Its synthesis, chemical behaviour and experimental production in man and monkeys. Quart. J. Med., 1941, 10 (n.s.), 95.

23. Hensley, W. J., and Blackburn, C. R. B., Electrophoretic identification of serum hemochromogens on filter paper. Australian J. Science, 1952, 15, 66.

24. Hensley, W. J., and Blackburn, C. R. B., Methemalbumin in the urine. Australian J. Science, 1953, 16(2), 64.

25. Maluf, N. S. R., Factors inducing renal shut-down from lysed erythrocytes: an experimental study. Ann. Surg., 1949, 130, 49.

26. Walsh, R. J., Personal communication.

27. Black, R. H., Personal communication.

28. Nelson, R. M., Eder, W. P., Eddy, F. D., Karlson, K. E., and Dennis, C., Production of a hemorrhagic state by the infusion of hemolysed blood. Proc. Soc. Exper. Biol. \& Med., 1950, 73, 208. 